\title{
Conceptualizing the European multilevel administrative order: capturing variation in the European administrative system
}

\author{
JARLE TRONDAL ${ }^{1,2}$ AND MICHAEL W. BAUER ${ }^{3}$ * \\ ${ }^{1}$ Department of Political Science and Management, University of Agder, Norway \\ ${ }^{2}$ ARENA Centre for European Studies, University of Oslo, Norway \\ ${ }^{3}$ Chair of Comparative Public Administration and Policy Analysis at the German University of Administrative Sciences \\ in Speyer
}

\begin{abstract}
Acknowledging that both analysts and practitioners face problems of meaningful categorization of social order in general, and the European political-administrative system in particular, this article suggests a conceptual frame through which European administrative order may be understood. Providing such a frame is important, because the catalogue of categories of the European Union (EU) polity developed so far fails to acknowledge its administrative dimension. Given that the ongoing political transformation in the EU implies ever more administrative interaction between political levels in order to coordinate, manage and implement policies, this administrative dimension becomes ever more important. This article thus sets out a threefold agenda: First, it offers a supplementary conceptual frame that takes the 'administrative dimension' seriously. It is suggested that the European politico-administrative organism should be conceived as a European multilevel administrative system (MLA) consisting of three dimensions: Institutional independence, integration and cooptation. Second, the article suggests how the MLA approach differs from one of its main conceptual rivals - the multilevel governance approach (MLG). Finally, the article offers some empirical illustrations of the value of the developed MLA approach for our understanding of the contemporary European administrative system.
\end{abstract}

Keywords: administrative order; cooptation; independence; integration; multilevel

\section{Introduction}

The recent economic crisis has contributed to what can be understood as 'institutional soul-searching' and the raising of questions about the nature of res publica (Emery and Giauque, 2014: 24). The challenge of understanding social and political order, however, is enduring for the social sciences (Waldo, 1992: 149). Unveiling social order involves disentangling causes of order formation and distortions (March and Olsen, 1989; Bartolini, 2005; Fukuyama, 2013; Padgett and Powell, 2012), consequences of order formation - especially how it challenges already existing orders (Olsen, 2007; Bickerton, 2012) - and suggesting how social order

\footnotetext{
* E-mail: Jarle.trondal@uia.no, michael.bauer@uni-speyer.de
} 
can be conceptualized. Perhaps unsurprisingly for a political system in the making, the institutional soul searching is particularly intense in the European Union (EU).

Before this background we attempt to advance our understanding of the European administrative order, which, in our view, is the backbone of the emerging political system of the EU. More concretely, we discuss avenues of how best to conceptualize this emerging administrative order. One enduring challenge in so doing, is to establish meaningful categories that capture the essential and enduring characteristics of such an order. Our starting assumption is therefore, that adequate analytical categories to classify contemporary European political-administrative life should offer more empirical variation between than within categories. Acknowledging that both analysts and practitioners face problems of meaningful categorization that capture essential aspects of social order in general (Waldo, 1992: 37; Painter and Peters, 2010: 6; Dahlstrom et al., 2012), and the European political-administrative system in particular, this paper suggests a conceptual frame through which administrative order may be understood. Putting, thus, the emphasis on administrative interaction and emerging structures is an attempt to rectify the ongoing debate about the nature of the EU polity in which the administrative dimension is by and large neglected. Be it constructivist perspectives (Checkel, 2005), intergovernmentalism (Moravcsik, 1998), or multilevel governance (MLG; Marks, 1993; Hooghe and Marks, 2001), administrative factors are usually treated as of secondary importance. This article follows a strand of thought from early neo-functionalism, where integration of bureaucratic elites were considered essential for European integration (Haas, 1958: 16), and also recent advances in neo-functionalist work by emphasising how organizations and ways of organizing may bias such processes (Niemann, 2006: 280; Sverdrup and Trondal, 2008; Niemann and Schmitter, 2009: 55). The ambition of this article is threefold:

- First, it offers a supplementary conceptual frame that takes the 'administrative dimensions' seriously. It is suggested that the European politico-administrative system needs to be understood as a European multilevel administrative system (MLA).

- Second, the ambition is to suggest how the MLA approach differs from what might be perceived as its main conceptual rival - the MLG approach.

- Finally, the article offers some empirical illustrations of how the MLA approach adds to our understanding of organizational formation and interaction in the contemporary European administrative system.

Despite attaching focal attention to the administrative dimensions of the EU polity, 'public administration' is not analyzed in isolation - as an 'intellectual wasteland' (Eluau, 1977: 421) - but rather as a set of capacities that mobilize systematic bias in the production of public policy (Gaus, 1950: 168; Schattschneider, 1975; Arellano-Gault et al., 2013: 154). Analyzing enduring patterns and dynamics of the administrative capacities of the EU are essential in our understanding of how public policy is shaped and executed. The MLA approach is thus also a theory of political organization. 
Two concerns underpin the relevance of choosing such a focus. First, there is a broader theoretical interest behind analyzing the patterns and dynamics of the EU administrative system. This theoretical agenda relates to the challenge that the emerging EU administrative system poses to the sub-discipline of public administration which has been largely locked in 'national laboratories' (Christensen and Lægreid, 2011; Verhoest et al., 2012). Theoretical lessons from social sciences are often affected by the empirical laboratories available to scholars. The domain of public administration is no exception. Theoretical advances may thus be gained by challenging methodological nationalism. As new forms of political and administrative orders emerge, they need to be appropriately analyzed and interpreted in view of the changes they carry for bureaucratic systems and public policy.

Second, the MLA approach directs attention toward an emergent administrative order in Europe through the development of novel institutional configurations. The more the EU is involved in policy coordination and implementation, the more important become issues of administrative interaction between the involved political levels - if only because the EU lacks an administrative basis to conduct 'supranational' policies independently from member states' administrative systems (Bauer, 2006a and 2006b; Heidbreder, 2011; Bauer and Becker, 2014). This line of research emphasizes patterns of integration of public administration - not its outcome. One early contribution to this line of research was an 'Italian law school' studying administrative engrenage (Berlin et al., 1987; Cassese, 1987; Chiti, 2004; Franchini, 2004). Contemporary public administration research has similarly been preoccupied with both understanding the European administrative capacity building (Egeberg, 2006; Rittberger and Wonka, 2011), and the interconnected nature of the European public administration (Curtin and Egeberg, 2008; Egeberg and Trondal, 2009; Egeberg, 2010). Illustrative of the latter approach, the European administrative system has been conceived of as a multilevel and nested network administration, though sometimes loosely coupled (Benz, 2012, 2015), where institutions at different levels of government 'are linked together in the performance of tasks...' (see also Eising and Kohler-Koch, 1999; Hofmann and Turk, 2006: 583).

Despite successful advances in conceptualizing the EU administrative system, we argue that two challenges plague contemporary public administration scholarship. First, public administration as 'a' sub-discipline (Raadschelders, 2011) has paid scant attention to ongoing transformations of bureaucratic interaction in the EU, and how this relates to other developments in public sector organizations (Verhoest et al., 2012). This literature has failed to acknowledge how shifting features of the state - such as agencification and subsequent networking of agencies - coexist with the rise of novel forms of multilevel administrative 'patterns' (Egeberg, 2006; Martens, 2010; Danielsen and Yesilkagit, 2014; Trondal, 2014). Much public administration literature has neglected that ways of organizing the making of public policy at one level may bias and 'lock in' ways of making public policy across levels. The administrative realities of the EU - perhaps with the exception of work concerning the European Commission - remains under-studied outside EU studies - even 
though it has received increased academic attention in recent years (Egeberg, 2006; Trondal, 2010; Ellinas and Suleiman, 2012; Kassim et al., 2013; Wille, 2013). Public administration scholars have, at best, imperfect and partial understandings of how the European administration function, how bureaucratic interactions occur horizontally and vertically among various political layers, how administrative structures across levels are developing, how precisely supranational administrative actors cultivate and use resources, and how national bureaucratic structures and actors adapt to and exploit respective constellations. From an administrative science perspective, it is of great importance to come to grips with the contemporary bureaucratic reality in the EU.

The article is continuous in the following steps: The next step outlines the MLA approach and the three analytical dimensions underneath. This section also subsequently shows how the MLA and the MLG approach are analytically distinct. According to an MLA approach, the European administrative system, and its component parts, is captured in this study along three analytical dimensions: (i) institutional independence, (ii) integration, and (iii) co-optation. These dimensions will subsequently serve, on the one hand, to capture central aspects of the integration of public administration in Europe, and on the other hand, to accentuate what makes the MLA approach different from its major rival - the MLG approach. The final section applies the MLA approach empirically and demonstrates why we should bother about the MLA approach.

\section{A multilevel administration (MLA) approach}

This section contributes in two important ways to our argument: First it outlines the contours of a MLA approach; second it discusses how this approach differs from the MLG approach.

During the past 2 decades, the multilevel character of the EU system has been intensively discussed (Marks, 1993; Piattoni, 2010). Referring to the EU as a multilevel system has become so colloquial that the term often gets used rather metaphorically, thereby hollowing out its analytical value. This has perhaps contributed to the fact that the mechanisms which fuel the transforming potential of the multilevel constellation of EU policy making remain vague and poorly understood in particular in view of their impact on the administrative dimension.

This article proposes that a 'level' refers to the following items: Separate and relatively independent sets of institutions, rules, procedures and personnel. Multilevel administration thus entails that a new platform emerges that interlinks these items at national level with parallel items at the level above. This platform of items consists of the paradoxical mix of institutional independence and institutional interconnectedness across levels of government. It consists of separate institutions (such as the Commission) that are able to act relatively independently from memberstate governments, and at the same time, have an institutional interconnectedness between the very same institutions (March, 1999). Already acknowledged by the 
MLG literature, understanding the dynamics of this paradoxical mix - of system independence and interdependence - is essential in order to gain an adequate understanding of the multilevel character of the EU administrative system (Marks et al., 1996a; Hooghe and Marks, 2001).

A core part of the literature on the European administrative system has centered on the emergence of a multilevel administrative system, sometimes characterized as a European administrative space (Trondal and Peters, 2013). This scholarship has been subdivided into a two-dimensional debate. First, a political science debate that tries to theoretically conceptualize MLG more broadly (Marks, 1993; Hooghe and Marks, 2001; Benz, 2012), and a more recent public administration debate that aims to understand the EU as a MLA (Egeberg, 2006; Trondal, 2007; Bauer and Trondal, 2015; Benz, 2015).

\section{Dimensions of MLA: institutional independence, integration, co-optation}

We can identify basically two waves of the study of 'MLA' (hereby termed 'MLA I' and 'MLA II'). This study draws attention to the second surge of research ('MLA II').

- 'MLA I': The first wave of research emphasized convergence of administrative systems and policies. This research measured MLA by its outcome - which were more convergent administrative forms, practices and ways of doing things. This research developed from the fields of comparative government and comparative public administration, studying, for example, origins and spread of common administrative traditions (Knill, 2001; Meyer-Sahling and Yesilkagit, 2011) and public management practices (Christensen and Lægreid, 2011). 'MLA' was conceived of as featuring the convergence of administrative systems around some shared forms, organizational standards, and values. One early contribution to this strand of research defined 'MLA' as European administrative convergence, or the 'convergence on a common European model' (Olsen, 2003: 506). One example is the seminal study of national co-ordination of EU policy by Kassim et al. (2000). They basically examined degrees of convergence of co-ordination arrangements in EU member-states. Amoretti and Musilla (2011) have more recently showed how e-government tools create shared and integrated digital administrative architectures in Europe. Several examples along the 'new governance' research track could be added.

- 'MLA II': A second and more recent line of research, conceives of 'MLA' as featuring an emergent common administrative order in Europe through the development of new institutional constellations and configurations (Benz, 2015; Heidbreder, 2015). This second line of research emphasizes new patterns or processes of integration of public administration - not its outcome. Research has been preoccupied with both understanding European administrative capacity-building (Bauer, 2006a and 2006b; Egeberg, 2006; Rittberger and Wonka, 2011), and understanding the interconnected nature of the European public administration (Curtin and Egeberg, 2008; Egeberg and Trondal, 2009; Egeberg, 2010). Illustrative of the latter approach, Hofmann and Turk (2006) conceive of 'MLA' as the emergence of a multilevel and nested 
network-administration where institutions at different levels of government 'are linked together in the performance of tasks...' (Hofmann and Turk, 2006: 583).

How, then, can one recognize 'MLA II' if it occurs? Following the second wave of 'MLA' research ('MLA II'), three proxies are suggested for analysis: institutional independence, integration and co-optation.

\section{Independence}

First, 'MLA II' involves institutionalizing some level of independent administrative capacity at a European level, notably the rise of relatively permanent and separate institutions that are able to act relatively independently from member-state governments. In his analysis of institutionalization in the context of political development, Huntington (1968) argued that autonomy was a first requirement of successful state development. An independent European administrative system must possess some capacity of its own (Zurn 2012: 731). Envisaged already by Saint-Simon in 1814 (1964: 35-38), one necessary factor in building common administrative systems - even common political order - is the establishment of common institutions, including a permanent congress independent of national governments serving the common interest. This article suggests how the growth of administrative capacities not only within the Commission, but also in institutions surrounding the Commission, may contribute to strengthening the independent capacities of the Commission - and thus facilitate the formation of 'MLA'. In addition to in-house organisational capacities, the Commission is supplied with the auxiliary capacities composed of expert committees and EU agencies. Independent administrative capacities will subsequently enable the independent development and implementation of public policy at, or from, a 'European' level.

\section{Integration}

Empirically it is often observed that the rise of common administrative space does not result in the institutionalization of coherent administrative capacities. Instead, different components of administrative centers do usually overlap, counteract, layer and sometimes be out of sync rather than being integrated, coordinated and 'ordered' (Orren and Skowronek, 2004). Supplementing the vertical specialization of administrative systems, the internal integration of administrative systems is also increasingly documented within national governments - notably reasserting centers of executive government (Peters, 2004; Poguntke and Webb, 2005). Similarly, one strand of contemporary research suggests that the Commission has become increasingly integrated - both within the Commission administration and between the Commission administration and the College of Commissioners (Wille, 2013). The history of the Commission documents periods of internal integration. Best known, perhaps, is the legacy of the Delors Commission (1985-94), characterized by presidential steering and a relative disregard of administrative routines 
(Kassim, 2006; Christiansen, 2008: 63). MLA thus centers attention on the extent to which we see inter- and intra-organizational coordination of EU-level administrative capacities - notably within the Commission - and the extent to which we observe parallel fragmentation, 'silo-ization', and sub-culturalization of the administrative services. The question remains also if these competing patterns of administrative integration and disintegration may co-exist within the European administration, albeit embedded and layered within different administrative sub-units. As shown in previous studies, administrative silo-ization is found at the heart of policy DGs in the Commission (Trondal, 2012) whilst at the same time we see organisational capacities emerging around the Commission President, partly by reforming the Secretariat-General (SG) into an administrative service center at the disposal of the President (Kassim et al., 2013).

\section{Co-optation}

The independence and integration of administrative capacities at the European level may not only have implications for how the Commission formulates and enacts public policy. The rise of independent and integrated European administrative capacities may also increase its ability to co-opt administrative sub-centers by stealth - notably EU agencies and domestic agencies, but probably also agencies within other international organizations thus reaching into global administrative architectures. The horizontal sector specialization of the Commission services may affect how the Commission co-opts administrative sub-units. This may be reflected in the development of direct links between Commissioners and 'their' EU agencies, as well as the development of relatively tight ties between Commission DGs and domestic agencies that work within similar policy fields. According to an MLA II approach, both horizontal networks of regulators (Yesilgakit, 2011) and domestic agencies (Egeberg and Trondal, 2009) may be co-opted by the Commission and offer supplies of relevant administrative capacities.

\section{MLG and multilevel administration}

The MLA II approach (hereafter termed MLA) highlights analytical dimensions largely left untouched by the MLG approach. The above analytical dimensions serve not only to capture central aspects of the integration of public administration in Europe, but also to accentuate what makes the MLA approach different from its major rival - the MLG approach: This section suggests that the MLG and MLA approaches mainly vary with respect to units of analysis, conceptions of the coherence of units, and sources of contingency of governance. Our point here is not to recap the MLG approach (Bache and Flinders, 2004; Hooghe and Marks, 2004; Piattoni, 2010), but to suggest how a MLA approach may offer attention to the administrative dimension of the European administrative system, which thus complements and helps in systematizing a more encompassing theory of MLG. 
First, the unit of analysis differs in MLG and MLA approaches. The MLG approach has both historically and contemporarily applied regions as their favorite unit of analysis (Marks et al., 1996b, 2008: 113; Piattoni, 2010). Focus has been on the relative autonomy of regions and how this autonomy supplies regions with a capacity to bypass state governments in their interaction with the Brussels apparatus. One conclusion is that the separation of domestic and international politics - and thus domestic and foreign affairs administrations - is ambiguous due to the interconnectedness of political authority across levels of governance (Hooghe and Marks, 2001: 4). In contrast, the MLA approach suggests that research focus should shift from regions towards the administrative interior of government institutions at different levels of government, principally towards administrative subunits at each level, and how these mutually relate. To illustrate, the MLA approach directs attention toward the behavior and role perceptions of unelected office holders (Trondal et al., 2010): the autonomy and interaction of subunits at each administrative level (Egeberg, 2006; Ege and Bauer, 2013; Trondal and Peters, 2013), the 'in-house' socialization processes of staff (Beyers, 2010), etc. Focus is thus not primarily on government apparatuses as arenas, but rather on government apparatuses as normative structures that mobilize bias (Schattschneider, 1975) and that contribute to a systematic patterning of behavioral patterns among office holders (Simon, 1957). Consequently, the way administrative subunits are formally organized at all levels of government is assumed to bias the roles, beliefs, identities, and behavior evoked by the staff involved, and ultimately the multilevel administrative governance processes being processed. Such organizational characteristics might include organizational capacity, organisational specialization (horizontal/vertical), organizational affiliation (primary/secondary), organizational coupling (tight/loose), etc.

Second, assumptions on the coherence of units of analysis vary between MLG and MLA approaches. Although the MLG approach successfully challenged the coherent nature of states (Piattoni, 2010: 2), at the same time, it largely treated its unit of analysis - regions - as coherent units of analysis. The definition of regions did not 'encompass possible sources of regional authority ...' (Marks et al., 2008: 113). Importantly, the dimensions applied to measure regional authority in the MLG approach did not contribute to unpack the organizational architecture of regions (Marks et al., 2008: 115 - Table 1). For example, the nine dimensions applied by Marks et al. (2008) to measure local authority aimed to gauge relationships between regions (as coherent black boxes) and national governments. None of these dimensions, however, suggested how the administrative interior of regions makes a difference in this regard. This lack of interest in the administrative inland of regions is a direct consequence of the fact that the MLG approach is basically interested in 'the allocation of authority across general purpose jurisdictions' and not the internal administrative architecture of regions as items for analysis (Marks et al., 2008: 111).

This lack of attention to the organizational dimensions of multilevel systems in the MLG approach is paralleled in international organization (IO) studies. 
Table 1. Key variations between the MLG and MLA approach

\begin{tabular}{|c|c|c|}
\hline & MLG & MLA \\
\hline Unit of analysis & Political arenas (regions) & $\begin{array}{l}\text { Administrative institutions (Public sector } \\
\text { organizations, and their sub-units) }\end{array}$ \\
\hline Organizational differentiation & $\begin{array}{l}\text { No differentiation (regions } \\
\text { as black boxes) }\end{array}$ & $\begin{array}{l}\text { High degree of differentiation } \\
\text { (administrative systems consisting of } \\
\text { horizontally and vertically specialized } \\
\text { sub-units) }\end{array}$ \\
\hline $\begin{array}{l}\text { Sources of contingency of } \\
\text { (administrative) governance }\end{array}$ & $\begin{array}{l}\text { The supply of regional } \\
\text { authority }\end{array}$ & $\begin{array}{l}\text { The supply of administrative capacities at } \\
\text { different levels of government }\end{array}$ \\
\hline
\end{tabular}

MLG = multilevel governance approach; MLA = multilevel administrative system.

Source: own compilation.

Recent research on governance in IOs pays only scant attention to the bureaucracies of these organizations (Karns and Mingst, 2004; Hawkins et al., 2006; but see Biermann and Siebenhühner, 2009; Bauer and Ege, 2014). One explanation for this lack of scholarly attention to the administrative dimension is partly the gulf that exists between IO literature and public administration literature. One clear example of this gulf is the book by Acharya and Johnston (2007) that makes a comparative analysis of IOs without mentioning their administrative systems. Rationalist accounts of IOs - the realist, neo-realist, and liberalist variants - treat international administrations as epiphenomena of the interaction of states. Studies of IOs have been preoccupied with studying the more visible interplay of states rather than the back-stage activities of the secretariats (Rochester, 1986). One notable exception is the growing volume of studies of the Commission and, to some extent, reports on the UN Secretariat (Egeberg, 2006; Chesterman, 2007). Researching the everyday decision making of international bureaucracies has been of less interest than studying the voting behavior of states in general assemblies (Hix, 2002), analyzing the great leaders of international bureaucracies, such as the UN General Secretary (Cox, 1969: 202; Rochester, 1986; Chesterman, 2007), and studying reforms of IOs (Bauer and Knill, 2007). Similarly, regime analysis tends to look at international administrations as intervening variables that 'somehow affect regime outcomes', thus not treating international administrations as institutions in their own right (Bauer, 2006b: 26; Underdal, 2008; Reinalda, 2013). Illustrative of this is the seminal work of Cox and Jacobson (1973: 428) which reflects this lack of administrative focus, concluding that international organizations facilitate the orderly management of intergovernmental relations without significantly changing the structure of power that governs these relations ...'. Discovering that international administrations can have identities, resources, authority, and interests of their own was, of course, an important development (Barnett and Finnemore, 2004). However, seen from a public administration point of view, these observations are less surprising (Ege and Bauer, 2013). The MLA approach treats their units of 
analysis as internally specialized. It is assumed that different degrees and types of organizational specialization - both at national and EU level - may have systematic implications on multilevel administrative governance processes.

Finally, MLG and MLA approaches diverge on core assumptions on the contingency of governance processes. The MLG approach has been successful in measuring regional authority, and thus in accounting for local conditions of multilevel processes (Marks et al., 2008). It is assumed that multilevel processes are primarily fostered by different degrees and types of regional autonomy, although contemporary MLG research is also increasingly interested in assessing IO authority (Hooghe and Marks, 2013). The MLG approach is theoretically actor-centered (Marks et al., 1996a: 348). To the extent that institutional variables enter the equation, they are treated as aggregative items (Marks et al., 1996b: 170) and thus compatible with a thin 'exchange based' conception of institutions. In such an account, 'politics can be seen as aggregating individual preferences into collective action by procedures of rational bargaining, negotiation, coalition formation, and exchange' (March and Olsen, 1995: 7). Institutional variables are merely treated as intervening variables that constrain purposeful action. Nowhere does the MLG approach 'unpack' institutions as independent variables. By contrast, the MLA approach assumes institutions as independent variables. One crucial causal mechanism in the MLA approach is the supply of administrative capacities at each level of government. It is suggested that the supply of organizational capacities at sub-unit level may have certain implications for how organizations and humans act. The MLA approach is thus also a theory of political organization. It is assumed that organizational capacity building provides government institutions with leverage to act independently and to integrate external institutions into their orbits. The MLA approach departs from the assumption that norms, rules, and routines embedded in institutions mobilize biases in public policy because these factors offer cognitive and normative shortcuts and categories that simplify and guide decision makers' search for satisficing and appropriate solutions (Simon, 1957; Cyert and March, 1963; Schattschneider, 1975; March and Olsen, 1989). Consequently, the decision-making behavior of 'Eurocrats' is likely to reflect their primary organizational embedment into government institutions and their sub-units.

Two empirical predictions follow from this assumption: First, the supply of independent administrative capacities is necessary for government institutions to act and to affect how other institutions act. Thus, the supply of administrative capacities in the Commission is expected to increase the likelihood that signals from the Commission will be ascribed importance by officials in other EU institutions and in domestic agencies. In effect, patterns of multilevel administrative governance between subunits are assumed to be supplied by the variety of administrative capacities of the Commission. Second, the behavior, role, and identity perceptions evoked by government officials are expected to be primarily directed towards those administrative subunits that are the primary supplier of relevant decision premises. 
It is assumed that multilevel administrative governance is facilitated by the organizational capacities of government subunits at both levels of government. One empirical implication is administrative integration along sectoral lines, for example between Commission DGs and agency subunits.

In sum, this section has suggested that the MLA approach is an important element in a broader theory of MLG than suggested by the MLG approach. The MLA approach may offer attention to the administrative dimension of the European administrative system and its added value is the conceptualization of administrative structures, values and interaction across levels of government - and is, therefore, a theory of political organization of the European administrative system.

\section{Why bother about the European administrative system? Empirical illustrations}

A complete empirical application of the MLA approach is beyond the remit of this article (Bauer and Trondal, 2015). The suggestive illustrations center on the core node of the European administration, namely its executive arm - the Commission. However, some footnotes are also offered to administrative sub-units outside the Commission, but which serve as part of the multilevel European administration. This section examines the European administrative system with regard to institutional independence, integration, and co-optation.

Academic interest in the administrative dimension of the European integration process grew in the aftermath of the European Single Act and the completion of the Common Market. It is perhaps no coincidence that the area from which this scholarly interest initially emerged was due to the questions concerning the coherent and uniform national implementation of policies agreed upon at EU level (Siedentopf and Ziller, 1988). It was the problem of 'making European policies work' coherently and timely, where the differential reality of national public administration systems came to the forefront (Knill, 2001).

Formulating and implementing public policy in Europe has historically been a prerogative of national administrations. The capacity of the state has largely been determined by 'the [administrative] capacity of the state to effectively achieve the chosen policy outcomes' (Matthews, 2012: 281). Recent studies, however, suggest that these prerogatives have become complemented with the rise in administrative capacities within and among EU institutions and their interaction with (sub) national actors (Genschel and Jachtenfuchs, 2014). A European administrative system serves to create an institutional infrastructure for the joint formulation and execution of public policy. The rise of a genuine European public administration is shown to reflect administrative capacity building, primarily in the Commission and EU agencies but increasingly also in domestic agencies and networks of regulatory agencies (Egeberg, Trondal and Vestlund, 2015a; Trondal, 2015). Capacity building at the EU center may subsequently strengthen the Commission's capacity to pursue independent policy formulation, to manage decentralized policy implementation, and to draw common lessons from experience. In this regard, the rise of 
a European administrative system at EU level may also strengthen the Commission's capacity to co-opt domestic non-majoritarian institutions and networks of these, thus integrating public administration in Europe across levels of government. Despite public administration being conceived of as a core state power (Genschel and Jachtenfuchs, 2014), capacity building in public administration serves to achieve regulatory integration in mostly non-core state policies.

\section{Institutional independence}

First, the rise of a European administrative system involves institutionalizing some degree of independent administrative capacity at European level, especially relatively permanent and separate institutions that are able to act fairly independently from member-state governments. The growth of administrative capacities, not only within the Commission but also in institutions surrounding the Commission, may contribute to strengthening the independent capacities of the Commission - thus facilitating the formation of a common European administrative system. In addition to in-house organizational capacities, the Commission has increasingly been supplied with auxiliary capacities composed of expert committees, EU agencies, networks of national regulators, and even the European Parliament (EP) administration.

Jean Monnet intended to create a small, independent, and entrepreneurial European executive institution above member-state governments for the ever-closer integration of states. However, following a steady growth of staff over the subsequent 60 years, the most recent expansion of the EU administration is found at the level below the Commission, notably among EU agencies (Egeberg and Trondal, 2011; Rittberger and Wonka, 2011; Busuioc et al., 2012). In the Commission literature a long-standing myth has challenged the idea of an independent Commission arguing that nationality fundamentally shapes the preferences of Commission staff and ultimately the internal functioning of the Commission (Kassim et al., 2013). However, more recent work reports that the Commission administration is able to act fairly independently of member-state governments. Studies suggest that the rise of organizational capacity inside the Commission, particularly in sectorally organized DGs, in practice, tends to safeguard its independence vis-à-vis member-state governments. Ellinas and Suleiman (2012: 65) show that top Commission bureaucrats tend to rely customarily on information from within the Commission administration. Moreover, Commission officials, also the seconded national experts, indicate a rather low degree of identification with their home governments and tend to have infrequent contact with their home administration (Murdoch and Trondal, 2013). Similar observations are made on position formation among permanent officials (Hartlapp et al., 2010) and on role perceptions among the College of Commissioners (Egeberg, 2006).

Faced with an increasing agenda overload, one supplementary strategy available to the Commission, in addition to building in-house administrative capacities, has 
been to import external experts when preparing legislative initiatives (Christiansen and Kirchner, 2000; Egeberg et al., 2003; Larsson, 2003; Gornitzka and Sverdrup, $2015)$. Studies suggest that expert committees tend, in practice, to strengthen the administrative capacity of the sectoral structure of the Commission administration for two main reasons. First, these committees are typically subordinated directly under respective DGs; most expert committees report to their parent DG and seldom to other DGs. Second, most expert committees are single-task entities largely mirroring the sector specialization of the DGs (see Gornitzka and Sverdrup, 2015). National government officials attending these committees also evoke a role perception that reflects their sector portfolios to a larger extent than their country of origin (Egeberg et al., 2003).

In addition, the Commission has EU agencies and networks of independent national agencies at its disposal (see Busuioc et al., 2012). First, EU agencies may supply the Commission with relevant administrative and executive capacity. The 'agency fever' at EU level has been accelerating fairly recently (Curtin and Dehousse, 2012) - since the early 1990s more than 30 regulatory EU agencies have been created. Several of the agencies currently existing are granted some degree of formal decision-making power, while the remaining agencies have tasks such as information gathering, technical support, and administration (Groenleer, 2009). Most EU agencies have restricted de jure powers, particularly with regard to making decisions. Still, studies document profound task expansion also among 'non-regulatory' EU agencies (Egeberg and Trondal, 2011). EU agencies, in practice, thus tend to supply the Commission with executive capacities at the implementation stage of the policy-making cycle. In addition to EU agencies, networks of national regulatory agencies have mushroomed, particularly with the role of facilitating the implementation of EU regulations (Egeberg et al., 2015c). These networks have developed largely on the basis of pre-existing structures (e.g. comitology committees), and have contributed to the accumulation and layering of independent administrative capacities that supports the independent implementation of EU regulations.

Finally, even the EP administration is shown to supply the Commission with relevant administrative capacities (Dobbels and Neuhold, 2015; Egeberg et al., $2015 \mathrm{~b})$. Since the EP was established, it has witnessed a profound growth in its General Secretariat. The EP Secretariat, however, has been observed to gravitate towards Commission DGs. For example, Egeberg et al. (2015b) show that EP officials enjoy a multiplicity of contacts as part of their daily work. However, the most important contact point reported is the Commission. EP officials also tend to emphasize, most strongly, arguments from the Commission, next to those from the Council. In short, the Commission seems to be the key interlocutor for the EP administration, although a systematic comparison with the Council Secretariat has not been reported (Egeberg et al., 2015c).

In summary, therefore, the Commission now has profound independent administrative capacities at its disposal, in addition to its increased in-house capacity. 


\section{Institutional integration}

Supplementing the vertical specialization of administrative systems, the internal integration of administrative systems is also increasingly debated and documented within national governments - notably reasserting centers of executive government (Peters, 2004; Poguntke and Webb, 2005). The literature has documented a pendulum shift from New Public Management reform measures toward 'joined-up government' in public sector organizations. The latter is seen as a wide-ranging concept geared toward reducing fragmentation of the public sector and public service delivery (Christensen et al., 2014: 443). In organisational terms, this shift has accompanied ambitions to build action capacities within government(s) generally and ambitions toward stronger political coordination of sub-ordinate agencies particularly. Increased national administrative coordination, in this sense, has been interpreted as a reaction to problems of governing a 'decentred public sector' (Peters, 2004: 131). Reasserting the center has had at least two ingredients: First, an ambition to centralize executive powers within national governments, and secondly to concentrate power resources around national executive heads (Dahlström et al., 2011).

In the European Union, studies have shown a relative intensifying of vertical administrative interactions - in particular after the Maastricht treaty went into force (Wessels, 1998, 2000). Again, this trend of increasing administrative interaction following ever greater political cooperation is best studied on the example of the European Commission. Studies suggest that the Commission has faced an enduring tension between administrative integration and disintegration - over time and in different parts of the services. One strand of contemporary research suggests that the Commission has become increasingly integrated - both within the Commission administration and between the Commission administration and the College of Commissioners - supported by an enhanced coordination role of the Secretariat General (Wille, 2013; Kassim et al., 2013). The history of the Commission documents periods of internal integration - the best known of which, perhaps, are the legacies of the Jean Monnet presidency and the Delors presidency. Essentially, however, the power-base of those presidents was largely based on their personal capacities and achievements. The power-base was, though, less safeguarded through administrative capacity building (Duchène, 1994; Drake, 2000). The contemporary internal integration of the Commission is centered on building organizational capacities around the President, partly by reforming the SG into an administrative service center at the disposal of the President (Kassim et al., 2013). Kassim et al. (2013) and Hartlapp et al. (2010, 2014), suggest that this bureaucratic integration is mainly forged by the Commission SG. Integration within the Commission administration is also observed with regard to intra-service decisionmaking processes, the rise of a common 'culture' across DGs, and structured relationships between the Commission administration and outside actors - such as international organizations, EU agencies, and domestic agencies (see Kassim et al., 2013; Murdoch and Trondal, 2013; Hartlapp, 2015). 
A second strand of research, however, highlights that the internal administrative integration of the Commission merely co-exists with administrative disintegration, 'silo-ization', and subculturalization of the Commission administration (Ellinas and Suleiman, 2012; Trondal, 2012). A recent study suggests that the integrative ambitions of the Commission President and the SG sometimes exceed their integrative capacities (Trondal, 2012). The horizontal interlocking role of the SG tends to collide with the organizational resources embedded in policy DGs, fuelling inter-DG conflicts of turfs and policies (Hartlapp et al., 2012: 27). The administrative integration of the Commission seems in practice to sometimes be thwarted by the horizontal specialization of the DGs and the influence of the most powerful DGs (Hartlapp et al., 2014).

In sum, despite observing a profound institutional independence in the European administration - notably within the Commission administration (see above), the same administrative apparatus faces a lasting tension between administrative integration and disintegration.

\section{Institutional co-optation}

Finally, the independence and integration of the Commission not only has implications for how Commission officials think and act. The rise of independent and integrated European administrative capacities also increases its ability to co-opt administrative sub-centers by stealth - particularly EU agencies and domestic agencies, but also agencies within other international organizations, thus reaching into global administrative architectures (see Gulbrandsen, 2012). Studies suggest that the inherent sectoral logic within Commission services has certain effects on its ability to co-opt administrative subunits. This is reflected in the development of direct links between Commissioners, DGs and 'their' partner EU agency (Groenleer, 2009: 130; Egeberg et al., 2014). A recent study confirms that the pivotal role of the Commission in the daily life of EU agencies is evident within policy areas in which the Commission has considerable organizational capacities at its disposal (Egeberg and Trondal, 2011). Moreover, at the policy formulation stage, the 'parent' Commission DG is seen by EU agency officials as particularly influential. At the policy implementation stage, in contrast, influence shifts towards one's own agency and national agencies, although at this stage the Commission is considered the most powerful institution outside one's own agency (Egeberg and Trondal, 2011). The Commission thus seems more vital in the daily life of EU agencies and thus, a de facto supplier of administrative capacities for the Commission. This is particularly so within policy areas in which the Commission has considerable organizational capacities at its disposal (see Hobolth and Martinsen, 2013).

Second, the sectoral organization of the Commission administration is also reflected in its relationships to domestic agencies and their administrative networks. Both horizontal networks of regulators (Yesilgakit, 2011) and domestic agencies (Egeberg and Trondal, 2009) seem to supply the Commission with relevant 
administrative capacities, particularly in the application of EU regulations. Domestic agencies organized at arm's length from ministerial departments enjoy a certain level of independence regarding their exercise of discretion. Recent studies suggest that even the daily practice of EU legislation at the national level no longer remains solely in the hands of national governments (Egeberg et al., 2015c).

In sum, studies document processes whereby the Commission DGs, in practice, co-opt administrative sub-units - notably EU agencies and domestic agencies. These processes are primarily observed at the implementation stage of the decisionmaking cycle, and in policy areas where the Commission DGs have substantial organizational capacities.

\section{Conclusion}

This article has suggested a conceptual frame through which administrative order may be understood. Arguably, the catalogue of categories of the EU polity fails to acknowledge the administrative dimension. The ambition of this study has been to offer a supplementary conceptual frame that takes the 'administrative dimensions' seriously, thereby also suggesting that previous accounts of the EU polity have left this dimension at the side. It is suggested that the European politico-administrative system should be conceived primarily as a European multilevel administrative system (MLA). Second, this article has suggested how the MLA approach differs from one of its conceptual rivals - the MLG approach. Finally, the study has offered some empirical illustrations of the MLA approach in the contemporary European administrative system.

In sum, the article suggests that the MLA approach is an important element in a broader theory of MLG than suggested by the MLG approach. The MLA approach may offer attention to the administrative dimension of the European administrative system and its added value is the conceptualization of administrative structures, values and interaction across levels of government - and is therefore a theory of political organization of the European administrative system.

The theoretical interest in the administrative dimension of the EU polity is related to the challenge that the emerging EU administrative system poses for the discipline of public administration which has been largely locked in national laboratories. Theoretical lessons from social sciences are arguably affected by the empirical laboratories available to scholars. The domain of public administration may arguably gain theoretical advances by challenging methodological nationalism. Moreover, despite successful advances in conceptualizing the EU administrative system, this article has argued that public administration, as a sub-discipline, has paid scant attention to ongoing transformations of bureaucratic interaction in the EU, and how this relates to other developments in public sector organizations. This literature has failed to account for how changing features of the state - such as agencification - impact and fuel the rise of novel forms of multilevel administrative governance. According to the MLA approach outlined here, the European 
administrative system, and its component parts, is taken seriously. This is captured along three analytical dimensions: institutional independence, integration, and co-optation. These dimensions serve first to capture central aspects of the integration of public administration in Europe, and second to accentuate what makes the MLA approach different from one of its rivals - the MLG approach.

Future studies applying the MLA approach would be potentially manifold. The MLA is of relevance for studying how federal-type systems - such as the EU integrate, and particularly the organizational dimension of such processes. This approach is also of relevance for studying the settlement of emergent organizations and organized systems. Organizations and organized systems are temporary settlements of rules and procedures, demography, locations, beliefs and norms. The MLA approach is particularly helpful in conceptualizing the settlement of emergent systems that involves multiple tiers of authoritative decision centers. Finally, we would also emphasize the attractiveness of studying the sustainability of the European administrative system. One way to do this would be to study how it operates under stress and turbulence. The sustainability and resilience of institutional independence, integration and cooptation may be taken for granted during periods of stability. During periods of turbulence, these items might be subject to test. Turbulent times - such as those typically associated with financial stress - are marked by the lack of 'order, rationality, control and predictability' (Cohen et al., 2012: 7). Turbulence is coined by long-term unruliness and tensions within environments and organizations - that might go unnoticed by practitioners and observers. As seen by the recent Euro-zone crisis in Europe, the Euro was marked by some kind of unsettledness already from the launch of the new Euro area, but the sudden crisis that hit Greece - and subsequent EU member states - unveiled the latent turbulent nature of the arrangement. During turbulence decision-makers face choices that need to be made under unfamiliar degrees of uncertainty (Tamuz and Lewis, 2008: 158). Turbulent times can reveal the fragility of institutions and produce surprising cascading dynamics that test the sustainability of existing governance arrangements. We suggest that turbulent times also represent an underappreciated opportunity to examine the resilience of organizations and organized systems. Less attended to by contemporary scholarship, unsettled systems of governance offer ample opportunity for scholarly reflection, stock taking, and suggest new ways forward (Olsen, 2007).

\section{Acknowledgments}

The study is financially supported from three basic research grants 'COMPOL: The Rise of Common Political Order' (University of Agder), 'EURODIV: Integration and division: Towards a segmented Europe?' (Norwegian Research Council), and the German Research Institute for Public Administration (GRIP). The authors acknowledge comments from two anonymous reviewers, the editors of the journal and Katerina Potapova for research assistance. 


\section{References}

Acharya, A. and A.I. Johnston (eds) (2007), Crafting Cooperation, Cambridge: Cambridge University Press. Amoretti, F. and F. Musella (2011), 'Towards the European administrative space: the role of e-government policy', European Political Science Review 3(1): 35-52.

Arellano-Gault, D., D. Demortain, C. Rouillard and J.C. Thoenig (2013), 'Bringing public organizations and organizing back in', Organization Studies 34(2): 145-167.

Bache, I. and M. Flinders (eds) (2004), Multi-level Governance, Oxford: Oxford University Press.

Barnett, M. and M. Finnemore (2004), Rules for the World, Ithaca: Cornell University Press.

Bartolini, S (2005), Re-Structuring Europe, Oxford: Oxford University Press.

Bauer, M.W (2006a), 'Co-managing programme implementation: conceptualizing the European commission's role in policy execution', Journal of European Public Policy 13(5): 717-735.

Bauer, S (2006b), 'Does bureaucracy really matter? The authority of intergovernmental Treaty secretariats in global environmental politics', Global Environmental Politics 6: 23-49.

Bauer, M.W. and C. Knill (eds) (2007), Management Reforms in International Organizations, Baden-Baden: Nomos.

Bauer, M.W. and S. Becker (2014), 'The unexpected winner of the crisis: the European commission's strengthened role in economic governance', Journal of European Integration 36(3): 213-229.

Bauer, M.W. and J. Ege (2014), 'The autonomy of international bureaucracies', in S. Kim, S. Ashley and H. Lambright (eds) Public Administration in the Context of Global Governance, Cheltenham: Edward Elgar, pp. 63-84.

Bauer, M.W. and J. Trondal (eds) (2015a), The Palgrave Handbook on the European Administrative System, Houndmills: Palgrave Macmillan.

Bauer, M.W. and J. Trondal (2015b), The administrative system of the European Union', in M.W. Bauer and J. Trondal (eds), The Palgrave Handbook of the European Administrative System, Houndmills: Palgrave Macmillan.

Benz, A. (2012), 'The European Union as a loosely coupled multi-level system', in H. Enderlein, S. Wälti and M. Zürn (eds), Handbook on Multi-level Governance, Cheltenham: Edward Elgar, pp. 214-226.

- (2015), 'European public administration as a multilevel system administration: a conceptual framework', in M.W. Bauer and J. Trondal (eds), The Palgrave Handbook on the European Administrative System, Houndmills: Palgrave Macmillan, pp. 31-47.

Berlin, D., S. Pag and C. Bourtembourg (eds) (1987), The European Administration, Maastricht: EAIP.

Beyers, J. (2010), 'Conceptual and methodological challenges in the study of European socialization', Journal of European Public Policy 17: 909-920.

Bickerton, C.J. (2012), European Integration, Oxford: Oxford University Press.

Biermann, F. and B. Siebenhüner (eds) (2009), Managers of Global Change: The Influence of International Environmental Bureaucracies, Cambridge, MA: MIT Press.

Busouic, M., M. Groenleer and J. Trondal (eds) (2012), The Agency Phenomenon in the European Union, Manchester: Manchester University Press.

Cassese, S. (1987), 'Divided powers: European administration and national bureaucracies', in D. Berlin, S. Pag and C. Bourtembourg (eds), The European Administration, Maastricht: EAIP.

Checkel, J.T. (2005), 'International institutions and socialization in Europe', International Organization 59: 801-826.

Chesterman, S. (ed.) (2007), Secretary or General?, Cambridge: Cambridge University Press.

Chiti, M.P. (2004), 'Forms of European administrative action', Law and Contemporary Problems 68: 37-57.

Christiansen, T. (2008), The Institutional Politics of the European Union, PhD Thesis. University of Maastricht.

Christiansen, T. and E. Kirchner (eds) (2000), Europe in Change, Manchester: Manchester University Press.

Christensen, T. and P. Lægreid (2011), 'Beyond NPM? Some development features', in T. Christensen and P. Lægreid (eds), The Ashgate Research Companion to New Public Management, Aldershot: Ashgate, pp. 391-404.

Christensen, T., A.L. Fimreite and P. Lægreid (2014), 'Joined-up government for welfare administration reform in Norway', Public Organization Review 14: 439-456. 
Cohen, M.D., J.G. March and J.P. Olsen (2012), “"A Garbage Can Model” at forty: a solution that still attracts problems', in A. Lomi and J.R. Harrison (eds), The Garbage Can Model of Organizational Choice: Looking Forward at Forty, Bingley: Emerald.

Cox, R.W. (1969), 'The executive head. An essay on leadership in international organization', International Organization 23: 205-230.

Cox, R.W. and H.K. Jacobson (1973), The Anatomy of Influence, New Haven: Yale University Press.

Curtin, D. and M. Egeberg (2008), 'Tradition and innovation: Europe's accumulated executive order', West European Politics 31: 639-661.

Curtin, D. and R. Dehousse (2012), 'European Union agencies: tipping the balance?', in M. Busuioc, M. Groenleer and J. Trondal (eds), The Agency Phenomenon in the European Union, Manchester: Manchester University Press, pp. 193-205.

Cyert, R.M. and J.G. March (1963), A Behavioral Theory of the Firm, Englewood Cliffs, NJ: Prentice Hall.

Dahlström, C., B.G. Peters and J. Pierre (eds), (2011), Steering from the Centre, Toronto: University of Toronto Press.

Dahlstrom, C., V. Lapuente and J. Teorell (2012), 'Public administration around the work', in S. Holmberg and B. Rothstein (eds), Good Government, Cheltenham: Edward Elgar, pp. 40-67.

Danielsen, O.A. and K. Yesilkagit (2014), 'The effects of European regulatory networks on the bureaucratic autonomy of national regulatory authorities', Public Organization Review 14: 353-371.

Dobbels, M. and C. Neuhold (2015), 'Officials 'pre-cooking' EU affairs? The role of EP officials in the ordinary legislative procedure (OLP)', in M.W. Bauer and J. Trondal (eds), The Palgrave Handbook of the European Administrative System, Houndmills: Palgrave Macmillan, pp. 246-262.

Drake, H. (2000), Jacques Delors, London: Routledge.

Duchène, F. (1994), Jean Monnet, New York: W. W. Norton \& Company.

Ege, J. and M.W. Bauer (2013), 'International bureaucracy from a public administration and international relations perspective', in B. Reinalda (ed.), Routledge Handbook of International Organization, London: Routledge, pp. 135-148.

Egeberg, M. (ed.) (2006), Multilevel Union Administration, Houndmills: Palgrave Macmillan.

— (2010), 'L'administration de l'Union Europeenne: niveaux multiples et construction d'un centre', Revue Francaise d'Administration Publique 133: 17-26.

Egeberg, M. and J. Trondal (2009), 'National agencies in the European administrative space: government driven, commission driven, or networked?', Public Administration 87: 779-790.

- (2011), 'EU-level agencies: new executive centre formation or vehicles for national control?', Journal of European Public Policy 18: 868-887.

Egeberg, M., G.F. Schaefer and J. Trondal (2003), 'The many faces of EU committee governance', West European Politics 26: 19-40.

Egeberg, M., J. Trondal and N.M. Vestlund (2015a), 'The quest for order: unravelling the relationship between the European Commission and European Union agencies', Journal of European Public Policy 22(5): 609-629.

Egeberg, M., Å. Gornitzka, J. Trondal and M. Johannessen (2015b), 'The European parliament administration: organizational structure and behavioral implications', in M.W. Bauer and J. Trondal (eds), The Palgrave Handbook of the European Administrative System, Houndmills: Palgrave Macmillan, pp. 227-245.

Egeberg, M., M. Martens and J. Trondal (2015c), 'EU's subordinated agency administration and the rise of executive power at the European level', in M.W. Bauer and J. Trondal (eds), The Palgrave Handbook of the European Administrative System, Houndmills: Palgrave Macmillan, pp. 329-348.

Eising, R. and B. Kohler-Koch (1999), 'Introduction: network governance in the European Union', in B. Kohler-Koch and R. Eising (eds), The Transformation of Governance in the European Union, London: Routledge.

Ellinas, A.A. and E. Suleiman (2012), The European Commission and Bureaucratic Autonomy, Cambridge: Cambridge University Press.

Emery, Y. and D. Giauque (2014), 'The hybrid universe of public administration in the 21st century', International Review of Administrative Sciences 80(1): 23-32. 
Eulau, H. (1977), 'The place of policy analysis in political science: five perspectives', American Journal of Political Science 21: 419-423.

Franchini, C. (2004), 'European principles governing national administrative proceedings', Law and Contemporary Problems 68(1): 183-196.

Fukuyama, F. (2013), 'What is governance?', Governance 26: 347-368.

Gaus, J.M. (1950), 'Trends in the theory of public administration', Public Administration Review 10(3): 161-168.

Genschel, P. and M. Jachtenfuchs (eds) (2014), Beyond the Regulatory Polity?, Oxford: Oxford University Press.

Gornitzka, A. and U. Sverdrup (2015), 'The expert-executive nexus in the European administrative system: expert groups and the European commission', in M.W. Bauer and J. Trondal (eds), The Palgrave Handbook of the European Administrative System, Houndmills: Palgrave Macmillan.

Groenleer, M. (2009), The Autonomy of European Union Agencies, Delft: Eburon.

Gulbrandsen, C. (2012), Europeanization in a global context. A study of a national maritime safety agency's work with global and European rules. PhD Thesis, University of Oslo.

Haas, E.B. (1958), The Uniting of Europe, Indiana: Notre Dame Press.

Hartlapp, M. (2015), 'Politicization of the European commission: when, how and with what impact?', in M.W. Bauer and J. Trondal (eds) The Palgrave Handbook of the European Administrative System, Houndmills: Palgrave Macmillan, pp. 145-160.

Hartlapp, M., J. Metz and C. Rauh (2010), 'The agenda set by the EU Commission: the result of balanced or biased aggregation of positions?', LEQS paper 21/2010.

- (2012), 'Which policy for Europe? Power and conflict over position formation inside the European Commission', paper presented at the workshop 'The transformation of the executive branch of government in Europe', 14-15 June, ARENA, University of Oslo.

Hartlapp, M., J.J. Metz and C. Rauh (2014), Which Policy for Europe?, Oxford: Oxford University Press.

Hawkins, D.G., et al. (eds) (2006), Delegation and Agency in International Organizations, Cambridge: Cambridge University Press.

Heidbreder, E.G. (2011), 'Structuring the European administrative space: policy instruments of multi-level administration', Journal of European Public Policy 18(5): 709-727.

- (2015), 'Horizontal capacity pooling: direct, decentralized, joint policy execution', in M.W. Bauer and J. Trondal (eds), The Palgrave Handbook on the European Administrative System, Houndmills: Palgrave Macmillan, pp. 369-382.

Hix, S. (2002), 'Parliamentary behavior with two principals: preferences, parties, and voting in the European parliament', American Journal of Political Science 46: 688-698.

Hofmann, H.C.H. and A.H. Turk (eds) (2006), EU Administrative Governance, Cheltenham: Edward Elgar.

Hooghe, L. and G. Marks (2001), Multi-Level Governance and European Integration, New York: Rowman \& Littlefield Publishers.

— (2004), 'Contrasting visions of multi-level governance', in I. Bache and M. Flinders (eds), Multi-Level Governance, Oxford: Oxford University Press.

Hooghe, L. and G. Marks (2013), 'Delegation and pooling in international organizations', The Review of International Organizations, pp. 1-24.

Huntington, S.P. (1968), Political Order in Changing Societies, New Haven, CT: Yale University Press.

Karns, M.P. and K.A. Mingst (2004), International Organizations, London: Lynne Rienner Publishers.

Kassim, H. (2006), 'The secretariat general of the European commission', in D. Spence (ed.), The European Commission, London: John Harper Publishing.

Kassim, H., B.G. Peters and V. Wright (eds) (2000), The National Co-Ordination of EU Policy: The Domestic Leve, Oxford: Oxford University Press.

Kassim, H., J. Peterson, M.W. Bauer, S. Connolly, R. Dehousse, L. Hooghe and A. Thompson (2013), The European Commission of the Twenty-First Century, Oxford: Oxford University Press.

Knill, C. (2001), The Europeanisation of National Administrations, Cambridge: Cambridge University Press. 
Larson, T. (2003), Precooking in the European Union. The World of Expert Groups. A Report to the Expert Group on Public Finance, Stockholm: Ministry of Finance, Ds 2003:16.

March, J.G. (1999), 'A learning perspective on the network dynamics of institutional integration', in M. Egeberg and P. Lægreid (eds), Organizing Political Institutions. Essays for Johan P. Olsen, Oslo: Scandinavian University Press, pp. 129-155.

March, J.G. and J.P. Olsen (1989), Rediscovering Institutions, New York: The Free Press.

— (1995), Democratic Governance, New York: The Free Press.

Marks, G. (1993), 'Structural policy and multilevel governance in the EC', in A.W. Cafruny and G.G. Rosenthal (eds), The State of the European Community: The Maastricht Debates and Beyond, Colorado: Lynne Rienner.

Marks, G., L. Hooghe and K. Blank (1996a), 'European integration from the 1980s: state-centric v. multi-level governance', Journal of Common Market Studies 34(3): 341-378.

Marks, G., F. Nielsen and L. Ray (1996b), 'Competencies, cracks, and conflicts. Regional mobilization in the European union', Comparative Political Studies 29(2): 164-192.

Marks, G., L. Hooghe and A.H. Schekel (2008), 'Measuring regional autority', Regional and Federal Studies 18: 111-121.

Martens, M. (2010), Organized Administrative Integration, ARENA Report 2, Oslo.

Matthews, F. (2012), 'Governance and state capacity', in D. Levi-Faur (ed.), The Oxford Handbook of Governance, Oxford: Oxford University Press, pp. 268-280.

Meyer-Sahling, J.H. and K. Yesilkagit (2011), 'Differential legacy effects: three propositions on the impact of administrative traditions on public management reform in Europe east and west', Journal of European Public Policy 18: 311-322.

Moravcsik, A. (1998), The Choice for Europe, Ithaca: Cornell University Press.

Murdoch, Z. and J. Trondal (2013), 'Contracted government. Unveiling the European commission's contracted staff', West European Politics 36(1): 1-21.

Niemann, A (2006), Explaining Decisions in the European Union, Cambridge: Cambridge University Press.

Niemann, A. and P.C. Schmitter (2009), 'Neofunctionalism', in A. Wiener and T. Diez (eds), European Integration Theory, Oxford: Oxford University Press, pp. 45-66.

Olsen, J.P. (2003), 'Towards a European administrative space?', Journal of European Public Policy 10(4): 506-531.

Olsen, J.P (2007), Europe in Search of Political Order, Oxford: Oxford University Press.

Orren, K. and S. Skowronek (2004), The Search for American Political Development, Cambridge: Cambridge University Press.

Padgett, J.F. and W.W. Powell (2012), The Emergence of Organizations and Markets, Princeton: Princeton University Press.

Painter, M. and B.G. Peters (eds) (2010), Tradition and Public Administration, Houndmills: Palgrave Macmillan.

Peters, B.G (2004), 'Back to the centre?: rebuilding the state', in G. Gamble (ed.), Restating the State, Oxford: Basil Blackwell, pp. 130-140.

Piattoni, S. (2010), The Theory of Multi-level Governance, Oxford: Oxford University Press.

Poguntke, T. and P. Webb (eds) (2005), The Presidentialization of Politics, Oxford: Oxford University Press.

Raadschelders, J.C.N. (2011), Public Administration, Oxford: Oxford University Press.

Rittberger, B. and A. Wonka (2011), 'Introduction: agency governance in the European Union', Journal of European Public Policy 18: 780-789.

Reinalda, B. (2013), 'International organization as a field of research since 1910', in B. Reinalda (ed.), Routledge Handbook of International Organization, London: Routledge, pp. 1-23.

Rochester, M.J. (1986), 'The rise and fall of international organization as a field of study', International Organization 40: 777-813.

Saint-Simon, H. (1964), Social Organization, The Science of Man and Other Writings, New York: Harper Torchbooks.

Schattschneider, E.E. (1975), The Semisovereign People, Fort Worth: Harcourt Brace Jovanovich College Publishers. 
Siedentopf, H. and J. Ziller (1988), Making European Policies Work: The Implementation of Community Legislation in the Member States. Volume I: Comparative Syntheses, EIPA: Bruylant: SAGE.

Simon, H.A. (1957), Administrative Behavior, 2nd edn., New York: Macmillan.

Sverdrup, U. and J. Trondal (eds) (2008), The Organizational Dimension of Politics, Bergen: Fagbokforlaget.

Tamuz, M. and E.T. Lewis (2008), 'Facing the threat of disaster: decision making when the stakes are high', in G.P. Hodgkinson and W.H. Starbuck (eds), The Oxford Handbook of Organizational Decision Making, Oxford: Oxford University Press, pp. 155-173.

Trondal, J. (2007), 'The public administration turn in integration research', Journal of European Public Policy 14: 960-972.

- (2010), An Emergent European Executive Order, Oxford: Oxford University Press.

- (2012), 'On bureaucratic centre formation in government institutions. Lessons from the European commission', International Review of Administrative Sciences 78: 425-445.

- (2014), 'Agencification', Public Administration Review 74(4): 545-549.

- (2015), 'The European administrative systems reassessed', in M.W. Bauer and J. Trondal (eds) The Palgrave Handbook of the European Administrative System, Houndmills: Palgrave Macmillan, pp. 482-505.

Trondal, J. and B.G. Peters (2013), 'The rise of European administrative space: lessons learned', Journal of European Public Policy 20(2): 295-307.

Trondal, J., M. Marcussen, T. Larsson and F. Veggeland (2010), Unpacking International Organisations, Manchester: Manchester University Press.

Underdal, A. (2008), 'The organizational infrastructure of international environmental regimes', in U. Sverdrup and J. Trondal (eds), The Organizational Dimension of Politics, Bergen: Fagbokforlaget.

Verhoest, K., S.V. Thiel, G. Bouckaert and P. Lægreid (eds) (2012), Government Agencies, Houndmills: Palgrave Macmillan.

Waldo, D. (1992), The Enterprise of Public Administration, Novato, California: Chandler \& Sharp Publishers.

Wessels, W. (1998), 'Comitology: fusion in action. Politico-administrative trends in the EU system', Journal of European Public Policy 5(2): 209-234.

— (2000), Die Öffnung des Staates: Modelle und Wirklichkeit grenzüberschreitender Verwaltungspraxis 1960-1995, Wiesbaden: Vs Verlag FR Sozialwissenschaften.

Wille, A. (2013), The Normalization of the European Commission, Oxford: Oxford University Press.

Yesilkagit, K. (2011), 'Institutional compliance, European networks of regulation and the bureaucratic autonomy of national regulatory authorities', Journal of European Public Policy 18(7): 962-979.

Zurn, M. (2012), 'Global governance as multi-level governance', in D. Levi-Faur (ed.), The Oxford Handbook of Governance, Oxford: Oxford University Press, pp. 730-744. 